\title{
ANALISIS PENGARUH KAPITALISASI PASAR DAN RASIO KEUANGAN TERHADAP RETURN SAHAM
}

\author{
AGUSTINUS SRI WAHYUDI \\ BENY \\ DANIEL \\ Trisakti School of Management, JI. Kyai Tapa No. 20, Jakarta, Indonesia \\ beny@stietrisakti.ac.id
}

\begin{abstract}
Stock returns are very important and become the main reason or objective for investors in investing. This study studies the effect of market capitalization and financial ratios on corporate stock returns. The independent variables used in this study are market capitalization to symbolize a company's market value and financial ratios such as earnings per share, debt to equity, return on assets, and current ratio. While the dependent variable is stock returns. The objects used in this study are property and real estate companies listed on the Indonesia Stock Exchange during the 2012-2017 period. The samples used in this study were collected using non-probability methods with purposive sampling techniques. Researchers use multiple regression models to examine the effect of independent variables that affect stock returns. The results showed that market capitalization had a positive effect on stock returns. While earnings per share, debt to equity, return on assets, and current ratio have no effect on stock returns.
\end{abstract}

Keywords: Return saham, kapitalisasi pasar, earnings per share, debt to equity, return on asset, current ratio

Abstrak: Return saham sangat penting dan menjadi alasan atau objektif utama bagi investor dalam melakukan investasi. Penelitian ini mempelajari tentang pengaruh dari kapitalisasi pasar dan rasio keuangan terhadap return saham perusahaan. Variabel independen yang digunakan dalam penelitian ini adalah kapitalisasi pasar untuk melambangkan nilai pasar sebuah perusahaan dan rasio keuangan seperti earnings per share, debt to equity, return on asset, dan current ratio. Sedangkan variabel dependen adalah return saham. Objek yang digunakan dalam penelitian ini adalah perusahaan properti dan real estate yang terdaftar di Bursa Efek Indonesia selama periode 2012-2017. Sampel yang digunakan dalam penelitian ini dikumpulkan dengan menggunakan metode non probabiliti dengan teknik purposive sampling. Peneliti menggunakan model regresi berganda untuk menguji pengaruh variabel independen yang mempengaruhi return saham. Hasil penelitian menunjukkan bahwa kapitalisasi pasar mempunyai pengaruh positif terhadap return saham. Sedangkan earnings per share, debt to equity, return on asset, dan current ratio tidak berpengaruh terhadap return saham.

Kata kunci: Return saham, kapitalisasi pasar, earnings per share, debt to equity, return on asset, current ratio

\section{PENDAHULUAN}

Persaingan industri semakin ketat dari tahun ke tahun sehingga setiap perusahaan baik perusahaan jasa maupun perusahaan barang akan melakukan berbagai cara untuk menjamin kelangsungan hidup perusahaannya. Untuk menjamin kelangsungan hidupnya, perusahaan dapat memanfaatkan sumber pendanaan baik 
melalui internal maupun eksternal. Pengelolaan dana dilakukan untuk memenuhi tujuan utama perusahaan yaitu untuk mensejahterakan pemegang saham (Gitman and Zutter 2015, 56). Kesejahteraan pemegang saham akan dapat tercapai apabila terjadi peningkatan perusahaan dalam menghasilkan laba (Prihantini, 2009). Terdapat beberapa cara untuk meningkatkan laba sebuah perusahaan. Beberapa cara yang dapat dilakukan perusahaan untuk tujuan meningkatkan labanya yaitu dengan meningkatkan kapasitas produksi dan berinvestasi pada pasar modal (Ulupui 2007). Meningkatkan kapasitas produksi dapat berujung kepada penjualan yang meningkat dan berpengaruh terhadap profit yang dapat digunakan untuk memnuhi tujuan utama perusahaan, yaitu mensejahterakan pemegang saham. Namun syarat yang harus dipenuhi untuk meningkatkan kapasitas produksi adalah tersedianya dana. Tanpa dana, perusahaan tidak akan bisa melakukan aktifitas produksi sehingga operasional perusahaan akan terhambat. Untuk mendapatkan dana perusahaan dapat menjual sahamnya kepada public (Putri 2012). Dari hasil penjualan saham tersebut, perusahaan mendapatkan suntikan dana yang dapat dijadikan modal untuk meningkatkan kapasitas produksi. Apabila perusahaan menempuh jalur pendanaan melalui penjualan saham kepada publikyang dimana perusahaan berada di posisi yang membutuhkan dana, berkebalikan dengan apabila perusahaan meningkatkan laba perusahaan melalui investasi di pasar modal yang dimana perusahaan mempunyai posisi sebagai pihak yang menyalurkan dana, kedua posisi tersebut penting untuk memahami dinamika harga saham (Rinati, 2012).

Dinamika harga saham dapat berupa kondisi pasar, kondisi mikro, kondisi makro, dan factor-faktor lainnya yang dapat mempengaruhi pergerakan saham suatu perusahaan. Namun return saham menjadi elemen yang paling penting dalam aktifitas pasar modal karena return saham merupakan tujuan utama investor dalam melakukan investasi (Idris dan Bala, 2015). Berbagai cara dapat dilakukan investor untuk mendapatkan return yang diharapkan, baik itu melalui saran yang didapatkan melalui broker, dealer, atau menajer invesyasi maupun melalui perilaku perdagangan di pasar saham.

Perilaku perdagangan saham di pasar modal dapat menentukan harga saham suatu perusahaan. Perilaku harga saham tersebutlah yang akan menentukan seberapa besar return yang mungkin bisa didapatkan seorang investor (Gunadi dan Kesuma 2015). Return saham adalah harapan yang diharapkan investor dari investasi di pasar saham yang dilakukannya. Return saham berupa selisih harga investasi saat ini yang lebih tinggi daripada saat periode awal sehingga akan terjadi capital gain, bila sebaliknya maka akan terjadi capital loss (Carlo 2014). Di dalam perdagangan pasar modal, investor dituntut untuk melakukan perencanaan yang efektif yang didasari oleh pengoptimalan keseimbangan antara jumlah return yang diharapkan dengan resiko yang dihadapi (Sillaban, 2007). Return mempunyai dua macam, yaitu return realisasi adalah return yang sudah terealisasikan dan dianalisis menggunakan data historis, dan return ekspesktasi yang merupakan return yang diharapkan (masa yang akan datang) (Hartono, 2010). Maka dari itu penelitian ini menggunakan lima variabel independen antara lain adalah Kapitalisasi Pasar untuk melambangkan nilai pasar perusahaan, Earnings Per Share (EPS), Debt to Equity (DER), Return On Asset (ROA), dan Current Ratio (CR) yang mewakili rasio keuangan perusahaan untuk mengukur kinerja keuangan perusahaan. Perusahaan yang 
mempunyai kapitalisasi pasar yang besar akan menjadi sasaran para investor untuk melakukan investasi jangka waktu yang panjang dikarenakan memiliki potensi perkembangan perusahaan yang tinggi dan memiliki resiko yang rendah. Saham yang berkapitalisasi pasar yang besar adalah saham dengan kapitalisasi pasar dengan nilai Rp 5 Triliun atau lebih (Faried, 2008). Penelitian Idris dan Bala (2015) menyatakan bahwa kapitalisasi pasar mempunyai pengaruh negatif signifikan terhadap return saham. Sedangkan penelitian Faried (2008) menyatakan kapitalisasi pasar tidak berpengaruh terhadap return saham. Earning Per Share adalah laba per lembar saham yang didapatkan oleh pemegang saham. EPS sering dipakai oleh investor sebagai rasio indicator keuangan yang digunakan untuk menganalisis atau menilai kemampuan perusahaan dalam menghasilkan laba untuk pemegang saham (Hermawan 2012). Penelitian Gunadi dan Kesuma (2015) menyatakan bahwa EPS memiliki pengaruh positif yang siginifikan terhadap return saham. Sedangkan penelitian yang dilakukan oleh Ulupui (2007) menyatakan earnings per share tidak berpengaruh terhadap return saham. Debt to Equity merupakan rasio yang menunjukkan kemampuan perusahaan untuk memenuhi kewajiban dengan menggunakan beberapa bagian dari modal sendiri berupa ekuitas untuk membayar hutang (Puspitadewi dan Rahyuda, 2016). Penelitian Puspitadewi dan Rahyuda (2016) menyatakan bahwa DER tidak memiliki hubungan yang signifikan terhadap return saham. Sedangkan menurut penelitian Gunadi dan Kesuma (2015) menyatakan debt to equity tidak berpengaruh terhadap return saham. Return On Asset adalah rasio profitabilitas yang digunakan untuk mengukur tingkat keefektivitas perusahaan dalam menghasilkan keuntungan dengan cara memanfaatkan aset yang dimilikinya (Prihantini, 2009). Menurut penelitian Puspitadewi dan Rahyuda (2016),
ROA memiliki pengaruh yang positif dan signifikan terhadap return saham suatu perusahaan. Sedangkan menurut penelitian Savitri (2012) menyatakan return on asset berpengaruh secara negatif dan tidak signifikan terhadap return saham. Current Ratio merupakan rasio likuiditas perusahaan yang menggambarkan kemampuan perusahaan dalam memenuhi kewajiban jangka pendeknya menggunakan aktiva lancar yang dimiliki. Penelitian yang dilakukan oleh Maitani et al. (2009) menyatakan bahwa Current Ratio memiliki pengaruh terhadap return saham. Sedangkan menurut Erari (2014) pada penelitiannya menyatakan bahwa current ratio tidak berpengaruh terhadap return saham.

\section{Teori Sinyal}

Secara umum, sinyal dapat diartikan sebagai isyarat dari pihak internal (manajemen) kepada pihak eksternal (investor). Sinyal yang diberikan dapat berbentuk dalam berbagai wujud, baik yang secara langsung dapat dipahami maupun yang harus melalui proses pemahaman secara mendalam untuk memahaminya (Gumanti, 2009). Menurut Gitman dan Zutter (2015, 586), teori sinyal adalah suatu tindakan keuangan oleh pihak manajemen keuangan untuk merefleksikan kondisi keuangan perusahaan tersebut kepada investor yang berpengaruh terhadap harga saham. Teori sinyal pertama kali dikemukakan oleh George A. Akerlof pada jurnalnya dengan teori "The Market For Lemons". Pihak perusahaan memiliki informasi yang lebih baik mengenai perusahaannya sendiri daripada pihak luar. Maka dari itu perusahaan harus memberi sinyal kepada pihak investor agar harga saham perusahaan dapat meningkat (Gumanti, 2009). Meningkatnya harga saham dari satu periode ke berikutnya akan mendatangkan return bagi investor. 


\section{Teori Agensi}

Menurut Gitman dan Zutter (2015, 68) masalah keagenan muncul ketika agen melenceng dari tujuan utamanya, yaitu mensejahterahkan sendiri daripada mensejaterahkan pemegang saham. Masalah ini yang pada akhirnya menimbulkan biaya keagenan. Untuk menghindari adanya tindakan agen yang tidak sesuai dengan prinsipal, agen perlu untuk diberikan insentif dan pengawasan yang mumpuni. Pengawasan terhadap agen dapat dilakukan dengan cara seperti pemeriksaan laporan keuangan berkala, dan melakukan pembatasan atas wewenang agen dalam mengambil keputusan. Dengan adanya upaya untuk mengendalikan agen tersebut, perusahaan membutuhkan biaya. Biaya untuk mengontrol agen dinamakan agency cost. Biaya agensi adalah segala biaya yang berhubungan dengan pengawasan terhadap agen agar mengambil keputusan dan bertindak sesuai dengan kepentingan prinsipal (Paramita dan Hidayanti, 2013).

Menurut Jensen dan Meckling (1967), biaya keagenan adalah biaya yang muncul dari gabungan beberapa aspek seperti pengeluaran biaya yang dilakukan oleh pemegang saham untuk mengawasi agennya, pengeluaran biaya oleh pemegang saham untuk membangun ikatan dengan agen, dan residual loss. Teori Pasar Efisien

Dalam pasar perdagangan saham, interaksi dari penjual dan pembeli akan menghasilkan harga ekuilibrium atau harga pasar. Dikarenakan arus informasi baru secara terus menerus dan tidak dapat terduga, harga saham akan selalu berfluktuasi bergerak menuju sebuah keseimbangan yang melambangkan informasi terbaru. Konsep ini dinamakan market efficiency (Gitman dan Zutter 2015, 330).

\section{Kapitalisasi Pasar}

Menurut pendapat dari Indaswari dan Mimba (2017) , kapitalisasi pasar adalah harga yang melambangkan nilai pasar suatu perusahaan yang diindikasikan dari jumlah saham yang beredar. Untuk mendapatkan nilai kapitalisasi pasar, harga penutupan pasar dikalikan dengan jumlah saham yang beredar. Sebuah perusahaan dikatakan berkapitalisasi pasar besar jika nilainya lebih besar atau sama dengan Rp. 5 Triliun.

$\mathrm{H}_{1}$ Kapitalisasi Pasar berpengaruhi terhadap return saham.

\section{Earnings Per Share}

Menurut Gunadi dan Kesuma (2015), eps adalah rasio perbandingan antara laba bersih setelah pajak dengan jumlah saham yang diterbitkan suatu perusahaan dan merupakan indikator yang paling sering digunakan investor untuk melakukan analisa kemampuan perusahaan untuk menghasilkan laba dari saham dalam mengambil keputusan investasi.

$\mathrm{H}_{2}$ Earnings Per Share berpengaruhi terhadap return saham.

\section{Debt to Equity}

Menurut Lestari et al. (2016), der adalah rasio leverage yang menunjukkan kemampuan perusahaan untuk membayar hutangnya dengan dengan menggunakan modal sendiri atau ekuitas yang dimilikinya. Tingkat DER yang aman untuk perusahaan adalah dibawah $50 \%$, semakin rendah DER melambangkan semakin aman kewajiban dapat dipenuhi oleh perusahaan menggunakan modal sendiri (Julianto dan Susanto 2017).

$\mathrm{H}_{3}$ Debt to Equity berpengaruhi terhadap return saham.

\section{Return on Asset}

Menurut Sudarsono dan Sudiyatno (2016), return on asset adalah rasio 
profitabilitas perusahaan untuk mengukur seberapa efektif perusahaan dalam menghasilkan laba dalam kegiatan operasionalnya dengan menggunakan aset yang dimilikinya. ROA menyebabkan perubahan harga saham yang juga merupakan elemen dalam menciptakan nilai perusahaan dalam menunjukkan prospek terhadap masa yang akan datang.

$\mathrm{H}_{4}$ Return On Asset berpengaruhi terhadap return saham.

\section{Current Ratio}

Menurut Prihantini (2009) Current Ratio adalah rasio yang digunakan untuk mengukur kemampuan perusahaan dalam memenuhi kewajiban jangka pendeknya menggunakan aktiva lancar yang dimililiki secara tepat pada waktunya.

$\mathrm{H}_{5}$ Current Ratio berpengaruhi terhadap return saham

\section{METODE PENELITIAN}

Perusahaan yang diteliti adalah perusahaan properti dan real estate yang memenuhi kriteria-kriteria penelitian di dalam periode 2012-2017. Prosedur pemilihan sampel dapat dilihat dalam tabel sebagai berikut :

Tabel 1 Pemilihan Sampel

\begin{tabular}{cc}
\hline $\begin{array}{c}\text { Prosedur Pembentukan Sampel } \\
\text { Kriteria Pemilihan Sampel }\end{array}$ & Jumlah \\
\hline $\begin{array}{c}\text { Perusahaan properti dan real estate } \\
\text { terdaftar di BEI Periode 2012-2017 }\end{array}$ & 48 \\
Perusahaan yang tidak memiliki data \\
keuangan yang berkaitan dengan \\
variabel penelitian secara lengkap \\
$\begin{array}{c}\text { Perusahaan yang tidak menerbitkan } \\
\text { laporan keuangan per 31 Desember } \\
\text { selama periode 2011-2017 } \\
\quad \text { Periode Penelitian }\end{array}$ \\
Jumlah data yang dijadikan sampel
\end{tabular}

Menurut Idris dan Bala (2015) return saham adalah tingkat pengembalian keuntungan yang dinikmati oleh pemodal atas investasi yang dilakukannya. Return saham merupakan hasil investasi saham yang berupa capital gain (loss), yaitu selisih antara harga saham saat ini dengan harga saham periode sebelumnya dibagi dengan harga saham periode sebelumnya. Menurut Ratnasari (2003), kapitalisasi pasar adalah harga pasar saham dikalikan dengan jumlah saham beredar. Secara matematis dapat dirumuskan seperti :

Kapitalisasi Pasar $=$ Harga Saham Pasar $\mathrm{x}$ Jumlah Saham Beredar
Earnings Per Share merupakan perbandingan antara laba bersih yang dihasilkan perusahaan melalui kegiatan bisnisnya dengan banyaknya jumlah saham yang beredar. EPS menggambarkan tingkat profitabilitas perusahaan yang digambarkan pada setiap lembar saham. Menurut Gunadi dan Kesuma (2015), untuk mengukur earnings per share digunakan rumus:

EPS = Laba Bersih / Jumlah Saham Beredar

Debt to Equity Ratio merupakan rasio hutang yang membandingkan total kewajiban sebuah perusahaan berupa hutang dengan total ekuitasnya. Menurut Lestari et al. (2016) DER secara matematis dapat dijelaskan dengan rumus sebagai berikut : 
Return On Asset merupakan rasio keuntungan yang digunakan untuk mengukur seberapa efektif perusahaan menghasilkan keuntungann atau profit menggunakan aktiva yang dimilikinya (Gitman and Zutter 2015, 130). $\mathrm{ROA}=$ Laba bersih setelah bunga dan pajakTotal Aktiva $\times 100$

Current Ratio merupakan rasio lancar untuk mengukur kemampuan likuiditas (solvabilitas jangka pendek) perusahaan yaitu kemampuan untuk membayar hutang yang segera harus dipenuhi dengan aktiva lancar (Ulupui 2007).
Current Ratio=Current AssetCurrent Liabilities

\section{HASIL PENELITIAN}

Hasil pengujian statistik deskriptif terhadap variabel yang digunakan dalam penelitian ini dapat dilihat pada tabel 2 sebagai berikut:

Tabel 2

Tabel 2 Statistik Deskriptif

\begin{tabular}{lllll}
\hline Variabel & Mean & $\begin{array}{l}\text { Maximu } \\
\mathbf{m}\end{array}$ & Minimum & $\begin{array}{l}\text { Deviasi } \\
\text { Standar }\end{array}$ \\
\hline RT & 0.067076 & 0.953100 & -0.72410 & 0.308694 \\
CAP & 0.946982 & 3.298933 & 0.12523 & 0.831501 \\
EPS & 118.7330 & 971.0000 & -8.65000 & 210.7347 \\
DER & 0.869653 & 3.700960 & 0.109730 & 0.548888 \\
ROA & 0.260389 & 9.420100 & -0.07000 & 1.345809 \\
CR & 2.294443 & 7.194000 & -3.47000 & 1.771849 \\
\hline
\end{tabular}

Hasil uji hipotesis menunjukan $\mathrm{H}_{1}$ diterima, maka terdapat pengaruh kapitalisasi pasar terhadap return saham. Hasil penelitian mendukung penelitian yang dilakukan oleh Idris dan Bala (2015) bahwa kapitalisasi pasar berpengaruh terhadap Return Saham.

Hasil uji hipotesis menunjukan $\mathrm{H}_{2}$ ditolak, maka tidak terdapat pengaruh Earnings Per Share terhadap return saham. Hasil penelitian konsisten dengan penelitian yang dilakukan oleh Ulupui (2007) yang menyatakan bahwa Earnings Per Share tidak berpengaruh terhadap Return Saham.

Hasil uji hipotesis menunjukan $\mathrm{H}_{3}$ ditolak, maka tidak terdapat pengaruh debt to equity terhadap return saham. Hasil penelitian konsisten dengan penelitian yang dilakukan Gunadi dan Kesuma (2015) bahwa Debt to Equity tidak berpengaruh terhadap Return Saham.

Hasil uji hipotesis menunjukan $\mathrm{H}_{4}$ ditolak, maka tidak terdapat pengaruh return on asset terhadap return saham. Hasil penelitian mendukung penelitian yang dilakukan Arista dan Astohar (2012) bahwa Return On Asset tidak berpengaruh terhadap Return Saham.

Hasil uji hipotesis menunjukan $\mathrm{H}_{5}$ ditolak, maka tidak terdapat pengaruh Current Ratio terhadap Return Saham. Hasil penelitian konsisten dengan penelitian yang dilakukan Erari (2014) bahwa Current Ratio tidak berpengaruh terhadap Return Saham.

\section{PENUTUP}

Kesimpulan penelitian ini adalah bahwa variabel earnings per share, debt to equity, return on asset, dan current ratio tidak berpengaruh terhadap return saham. Sedangkan variabel kapitalisasi pasar memiliki pengaruh terhadap return saham. 


\section{REFERENCES:}

Adiwiratama, Jundan. 2012. Pengaruh Informasi Laba, Arus Kas dan Size Perusahaan Terhadap Return Saham (Studi Empiris Pada Perusahaan Manufaktur Yang Terdaftar di BEI). Singaraja. Jurnal IImiah Akuntansi dan Humanika.

Anderson, David R., Dennis J., Sweeney and Thomas A Williams. 2014. Statistics for business and Economics, Twelfth Edition. United States of America : South Western, Cengage Learning.

Arista, Desy dan Astohar. 2012. Analisis Faktor-Faktor Yang Mempengaruhi Return Saham (Kasus Pada Perusahaan Manufaktur yang Go-Public di BEI Periode tahun 2005-2009). Semarang.

Budialim, Giovanni. 2013. Pengaruh Kinerja Keuangan dan Resiko Terhadap Return Saham Perusahaan Sektor Consumer Goods di Bursa Efek Indonesia Periode 2007-2011. Jurnal IImiah Mahasiswa Universitas Surabaya Vol. 2 No. 1.

Dewi, Putu Dina Aristya dan I.G.N.A Suaryana. 2013. Pengaruh EPS, DER, dan PBV Terhadap Harga Saham. EJurnal Akuntansi Universitas Udayana 4.1..

Erari, Anita. 2014. Analisis Pengaruh Current Ratio, Debt to Equity Ratio, dan Return On Asset Terhadap Return Saham Pada Perusahaan Pertambangan di Bursa Efek Indonesia. Jurnal Manajemen dan Bisnis Vol .5 No. 2.

Gitman, Lawrence J., and Chad J. Zutter. 2015. Principles of Managerial Finance, Fourteenth Edition. United States of America: Pearson Education

Gumanti, Tatang Ary dan Elok Sri Utami. 2002. Bentuk Pasar Efisiensi dan Pengujiannya. Jurnal Akuntansi dan Keuangan Vol. 4 No.1..

Gunadi, Gd Gilang dan I Ketut Wijaya Kesuma. 2015. Pengaruh ROA, DER, EPS Terhadap Return Saham Perusahaan Food and Beverage BEl. E-Jurnal Manajemen Unud Vol. 4 No.6.

Hamidy, Rahman Rusdy, I Gusti Bagus Wiksuana dan Luh Gede Sri Artini. 2015. Pengaruh Struktur Modal Terhadap Nilai Perusahaan Dengan Profitabilitas Sebagai Variabel Intervening Pada Perusahaan Properti dan Real Estate di Bursa Efek Indonesia. E-Jurnal Ekonomi dan Bisnis Universitas Udayana Vol. 4 No.10.

Hartono, Jogiyanto. 2008. Teori Portofolio dan Analisis Investasi. BPEE UGM: Yogyakarta.

Hermawan, Dedi Aji. 2012. Pengaruh Debt to Equity Ratio, Earning Per Share dan Net Profit Margin Terhadap Return Saham. Management Analysis Journal 1 (5)..

Idris, Ibrahim and Hussaini Bala. 2015. Firms' Specific Characteristics and Stock Market Returns (Evidence From Listed Food and Beverages Firms In Nigeria). Research Journal of Finance and Accounting..

Indraswari, I Gusti Ayu Laksmi dan Ni Putu Sri Harta Mimba. 2017. Pengaruh Profitabilitas, Pertumbuhan Perusahaan, Kapitalisasi Pasar dan Kepemilikan Saham Publik Pada Tingkat Pengungkapan CSR. E-Jurnal Akuntansi Universitas Udayana Vol. 20 No.2.

Jensen, Michael J., and William H Meckling. 1976. Theory of The Firm : Managerial Behavior, Agency Costs and Ownership Structure. Jurnal of Financial Economics Vol. 3 No.4.

Julianto, T, \& Susanto, Y.K. 2017. Value Added Intellectual Coefficient Dan Stock Return. Jurnal Wira Ekonomi Mikroskil: JWEM, 7(1), 79-88.

Keown, Arthur J., John D. Martin., J. William Petty. 2014. Foundation of Finance: The Logic and Practice of Financial Management, eight edition. England: Pearson Education Limited.

Lestari, Kurnia, Rita Andini dan Abrar Oemar. 2016. Analisis Likuiditas, Leverage, Profitabilitas, Aktivitas, Ukuran Perusahaan dan Penilaian Pasar Terhadap Return Saham (Pada Perusahaan Real Estate dan Properti di BEI) Periode Tahun 2009-2014. Jurnal of Accounting Vol. 2 No.2.

Martani, Dwi, Mulyono, dan Rahfiani Khairuzizka. 2009. The Effect of Financial Ratios, Firm Size, and Cash Flow From Operating Activities In The Interim Report To The Stock Return. Chinese Business Review Vol. 8 No. 6. 
Rosdakarya. Paramita, Ratna Wijayanti Daniar dan Ery Hidayanti. 2013. Pengaruh Earning Response Coefficient (ERC) Terhadap Harga Saham (Studi Pada Perusahaan Manufaktur Yang Terdaftar di Bursa Efek Indonesia). Jurnal WIGA Vol.3 No. 1.

Pratiwi, Nining dan I. Kt. Suryanawa. 2014. Pengaruh Good Corporate Governance dan Corporate Social Responsibility Disclosure Pada Return Saham. E-Jurnal Akuntansi Universitas Udayana Vol. 9 No.2.

Puspitadewi, Cokorda Istri Indah dan Henny Rahyuda. 2016. Pengaruh DER, ROA, PER Dan EVA Terhadap Return Saham Pada Perusahaan Food And Beverage di BEl. E-Jurnal Manajemen Unud Vol. 5 No. 3.

Raningsih, Ni Kadek dan I Made Pande Dwiana Putra. 2015. Pengaruh Rasio-Rasio Keuangan Dan Ukuran Perusahaan Pada Return Saham. E-Jurnal Akuntansi Universitas Udayana Vol. 13 No. $2 .$.

Sillaban, Anni. 2007. Analisis Faktor-Faktor Yang Mempengaruhi Return Saham Perusahaan Manufaktur Yang Go Publik di Bursa Efek Indonesia. Jurnal Majalah Ekonomi.

Sudarsono, Bambang dan Bambang Sudiyatno. 2016. Faktor-Faktor Yang Mempengaruhi Return Saham Pada Perusahaan Properti dan Real Estate Yang Terdaftar Pada Bursa Efek Indonesia Tahun 2009 s/d 2014. Jurnal Bisnis dan Ekonomi Vol. 23 No. 1.

Sugiyono. 2014. Metode Penelitian Bisnis (Pendekatan Kuantitatif, Kualitatif, dan R\&D). Bandung: ALFABETA

Sunardi, Harjono. 2010. Pengaruh Penilaian Kinerja Dengan ROI dan EVA Terhadap Return Saham Pada Perusahaan Yang Tergabung Dalam Indeks LQ-45 di Bursa Efek Indonesia. Jurnal Akuntansi Vol. 2 No. 1. Susilowati, Yeye dan Tri Turyanto. 2011. Reaksi Signal Rasio Profitablititas dan Rasio Solvabilitas Terhadap Return Saham Perusahaan. Dinamika Keuangan dan Perbankan.

Ulupui, I.G.K.A. 2007. Analisis Pengaruh Rasio Likuiditas, Leverage, Aktivitas, dan Profitabilitas Terhadap Return Saham (Studi Pada Perusahaan Makanan dan Minuman Dengan Kategori Industri Barang Konsumsi di BEJ). Jurnal IImiah Akuntansi dan Bisnis.

Wijaya, Renny. 2013. Pengaruh Fundamental Ekonomi Makro Terhadap Indeks Harga Saham Gabungan Pada Bursa Efek Indonesia Periode 2002-2011. Jurnal IImiah Mahasiswa Universitas Surabaya Vol. 2 No. 1. 